\title{
HYDROPONICS SYSTEM AS AN ALTERNATIVE TO SOIL FARMING OF WATERMELON IN NIGERIA
}

\author{
Ossai, C. O. (Corresponding Author) \\ Research Supervisor \\ YIIFSWA Project, International Institute of Tropical Agriculture, Ibadan, Nigeria \\ E-mail: c.ossai@cgiar.org \\ Ojobor, S. A. \\ Senior Lecturer \\ Department of Agronomy, Delta State University, Abraka, Delta State, Nigeria \\ E-mail: smartojobor@gmail.com
}

\author{
Akpeji, S. C. \\ Graduate Student \\ Microbiology Department, University of Ibadan, Ibadan, Nigeria \\ E-mail: akpejistephanie@gmail.com
}

Oroghe, O. E.

Graduate Student

Crop Protection and Environmental Biology Department, University of Ibadan, Nigeria

E-mail: elohooroghe@gmail.com

Ogbole, $\mathbf{S}$.

Graduate Student

Biochemistry Department, Federal University of Agriculture, Abeokuta, Nigeria

E-mail: ogbolesamson@gmail.com

Received: July 15, 2021 Accepted: August 29, 2021 Online Published: September 08, 2021

DOI: 10.46545/aijas.v5i1.200

URL: https://doi.org/10.46545/aijas.v5i1.200

\begin{abstract}
Watermelon is an important vegetable consumed worldwide. It is mostly grown in a sandy loam soil with a pH value ranging from 6.5 to 7.5 . However, due to the constraints in land accessibility coupled to the farmers-herders clashes for limited land resources in Nigeria, it is important to shift the focus from land extensification to intensification farming. This study therefore compares the potential of hydroponics system of cultivating watermelon relative to conventional soil farming system. Three varieties of water melon (Diamond black, Crimson sweet and Travelers watermelon varieties) were planted in 2 substrate conditions (soil and cocopeat) $4 \mathrm{~kg}$ each. It was a $3 \times 2$ factorial experiment arranged in a completely randomized
\end{abstract}


design with 3 replicates. Data were collected on the agronomic and yield parameters, and analysed using ANOVA, and means were separated using LSD at 5\% level of significance. Results obtained showed varied agronomic performances among the genotypes, while the Crimson sweet watermelon produced significantly heavier fruit size $(5.38 \pm 0.34)$ compared to the rest genotype. However, the highest number of fruits $(2.33 \pm 0.22)$ was obtained in the soil, but the substrate type was insignificant in the average fruit weight. Hence, the hydroponics system is recommended as a complementary alternative to soil farming.

Keywords: Watermelon, Cocopeat, Soil, Substrates; Agronomic Performance, Yield Performance.

\section{JEL Classification Codes: Q11.}

\section{INTRODUCTION}

Fruits like watermelon is a good source of natural essential elements which are consumed by man to nourish the body and act as a preventive mechanism against several diseases by building the immune system (Reetu \& Maharishi, 2017). Most bye-products of these fruits are also used in the pharmaceutical companies for the production of supplements (Naz et al., 2013). However, not only are these fruits useful in drug production, but they can be consumed fresh by humans, thereby making these essential elements also available to humans.

The pressure on watermelon supply calls for an increased production to meet the consumer needs, and this makes it important to consider a good edaphic and climatic conditions to boost its productivity. Watermelon is reportedly grown in a sandy loam soil with a $\mathrm{pH}$ value ranging from 6.5 to 7.5 (Kumar et al., 2013). However, due to the constraints in land accessibility coupled to the farmers-herders clashes for limited land resources, it is important to shift the focus from extensification (cultivating large expanse of land) to intensification (the use of small land area with more inputs) to boost watermelon production (Peter, 2018).

However, for the sustainability of the production in a vertical farming system (soilless farming), it is important to exploit different varieties of watermelon in order to establish their stability for production in Nigeria greenhouses by comparing their productivity with the soil system. Thus the purpose of setting up this study.

\section{MATERIALS AND METHODS}

Three varieties of watermelon (Diamond black, Crimson sweet and Travelers watermelon varieties) were sourced from the Soilless Farmlab, Abeokuta, Nigeria. The seeds were sown directly into a $4 \mathrm{~kg}$ trough (one part containing buffered and dissolved cocopeat and the second part contained loamy soil) (4 seeds per trough). $250 \mathrm{~g}$ of poultry manure were applied to the $4 \mathrm{~kg}$ trough and kept in a screen house were there were been watered thrice a week till harvest and were twined with thread and stick to avoid intertwining. The experiment was a 2 (substrates) by 3 (varieties) factorial arranged in a completely randomized design with three replicates. The agronomic data were taken on the plants include the plant height, number leaves and leave area, days to $50 \%$ flowering, days to fruiting, number of fruits produced and the fruit weight were also taken. Data collected were analysed using ANOVA (SAS 9.0 version) and differences in the treatment means were separated using Least Significant Differences (LSD) at 5\% level of significance. 


\section{RESULTS}

Results obtained showed that at 2 weeks after planting (2WAP), the plant height and number of leaves produced by the genotypes were insignificant. However, the leaf area of the BD genotype $(10.33 \pm 0.57)$ was significantly higher than the CS $(5.50 \pm 0.26)$ and TSO $(5.45 \pm 0.26)$ genotypes (Table 1). At 4 WAP, the number of leaves produced by CS $(8.00 \pm 0.36)$ was significantly higher than the rest genotypes, whereas the leaf area of the BD genotype (14.15 \pm 0.62$)$ was significantly higher than the rest genotypes, while the substrate type was insignificant in the growth parameters estimated (Table 2).

Table 1. Agronomic performances of three varieties of watermelon grown in soil and soilless system

\begin{tabular}{|l|l|l|l|l|l|l|}
\hline Genotypes & PH2 & NOL2 & LA2 & PH4 & NOL4 & LA4 \\
\hline Diamond black & $15.08 \mathrm{a}$ & $4.25 \mathrm{a}$ & $10.33 \mathrm{a}$ & $17.08 \mathrm{a}$ & $6.63 \mathrm{~b}$ & $14.15 \mathrm{a}$ \\
\hline Crimson sweet & $15.01 \mathrm{a}$ & $4.25 \mathrm{a}$ & $5.50 \mathrm{~b}$ & $17.13 \mathrm{a}$ & $8.00 \mathrm{a}$ & $9.69 \mathrm{~b}$ \\
\hline $\begin{array}{l}\text { Travelers } \\
\text { watermelon }\end{array}$ & $12.43 \mathrm{~b}$ & $4.75 \mathrm{a}$ & $5.45 \mathrm{~b}$ & $17.69 \mathrm{a}$ & $7.00 \mathrm{ab}$ & $9.88 \mathrm{~b}$ \\
\hline LSD $(0.05)$ & 1.01 & 0.76 & 1.69 & 2.5 & 1.06 & 1.83 \\
\hline SE & 0.34 & 0.26 & 0.57 & 0.84 & 0.36 & 0.62 \\
\hline
\end{tabular}

Means with the same letter down the group are not significantly different from each other at 5\% level of significance. LSD: Least significant difference, SE: Standard error, PH: Plant height, NOL: Number of leaves, LA: Leaf area.

Table 2. Effect of substrate types (soil and cocopeat) on the agronomic performances of watermelon

\begin{tabular}{|l|l|l|l|l|l|l|}
\hline Substrates & PH2 & NOL2 & LA2 & PH4 & NOL4 & LA4 \\
\hline Cocopeat & $14.43 \mathrm{a}$ & $4.42 \mathrm{a}$ & $6.66 \mathrm{a}$ & $17.03 \mathrm{a}$ & $7.50 \mathrm{a}$ & $10.55 \mathrm{a}$ \\
\hline Soil & $13.91 \mathrm{a}$ & $4.42 \mathrm{a}$ & $7.53 \mathrm{a}$ & $17.56 \mathrm{a}$ & $6.92 \mathrm{a}$ & $11.93 \mathrm{a}$ \\
\hline LSD(0.05) & 0.82 & 0.62 & 1.38 & 2.04 & 0.86 & 1.5 \\
\hline SE & 0.28 & 0.21 & 0.46 & 0.69 & 0.29 & 0.5 \\
\hline & & & & & & \\
\hline $\begin{array}{l}\text { Genotypes X Substrates } \\
\text { interaction }\end{array}$ & $0.18 \mathrm{~ns}$ & $1.50 \mathrm{~ns}$ & $4.31 \mathrm{~ns}$ & $12.04 \mathrm{~ns}$ & $3.79^{*}$ & $18.17 \mathrm{~ns}$ \\
\hline
\end{tabular}

Means with the same letter down the group are not significantly different from each other at 5\% level of significance. LSD: Least significant difference, SE: Standard error, PH: Plant height, NOL: Number of leaves, LA: Leaf area.

However, the number of days taken by the TSO genotype $(42.25 \pm 0.62)$ was significantly higher than the BD $(39.63 \pm 0.62)$ and CS $(38.38 \pm 0.62)$ which took the shortest number of days to reach $50 \%$ flowering. Also the TSO genotype took an average of $62.63 \pm 0.69$ days to produce fruits, which was significantly lower than the $59.50 \pm 0.69$ days taken by the CS genotype which produced significantly heavier fruits $(5.38 \pm 0.34)$ than the rest genotypes (Table 3$)$. However, the number of days taken by the genotypes to produce fruits in the cocopeat substrate $(61.92 \pm 0.57)$ 
was significantly higher than the $59.58 \pm 0.69$ days spent to produce fruits in the soil, and the number of fruits produced by the genotypes in the soil system $(2.33 \pm 0.22)$ was significantly

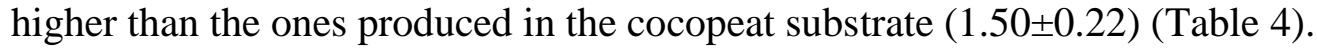

Table 3. Average yield performances of three varieties of watermelon

\begin{tabular}{|l|l|l|l|l|}
\hline Genotypes diamond & DT50\%F & DTFruiting & NOF & FW $(\mathrm{kg})$ \\
\hline $\begin{array}{l}\text { Black } \\
\text { watermelon }\end{array}$ & $60.63 \mathrm{~b}$ & $1.88 \mathrm{a}$ & $3.50 \mathrm{~b}$ \\
\hline $\begin{array}{l}\text { Crimson } \\
\text { watermelon }\end{array}$ & $38.38 \mathrm{~b}$ & $59.50 \mathrm{~b}$ & $1.75 \mathrm{a}$ & $5.38 \mathrm{a}$ \\
\hline Traveler watermelon & $42.25 \mathrm{a}$ & $62.63 \mathrm{a}$ & $2.13 \mathrm{a}$ & $3.38 \mathrm{~b}$ \\
\hline LSD $(0.05)$ & 1.83 & 2.06 & 0.8 & 1.02 \\
\hline SE & 0.62 & 0.69 & 0.27 & 0.34 \\
\hline
\end{tabular}

Means with the same letter down the group are not significantly different from each other at $5 \%$ level of significance. LSD: Least significant difference, SE: Standard error, DT50\%F: Days to 50\% flowering, DTFruiting: Days to fruiting, NOF: Number of fruits and FW: Fruit weight.

Table 4. Effect of substrate types (soil and cocopeat) on the yield performances of watermelon

\begin{tabular}{|l|l|l|l|l|}
\hline Substrates & DT50\%F & DTFruiting & NOF & FW $(\mathrm{kg})$ \\
\hline Cocopeat & $40.08 \mathrm{a}$ & $61.92 \mathrm{a}$ & $1.50 \mathrm{~b}$ & $4.17 \mathrm{a}$ \\
\hline Soil & $40.08 \mathrm{a}$ & $59.58 \mathrm{~b}$ & $2.33 \mathrm{a}$ & $4.00 \mathrm{a}$ \\
\hline LSD $(0.05)$ & 1.49 & 1.69 & 0.66 & 0.83 \\
\hline SE & 0.5 & 0.57 & 0.22 & 0.28 \\
\hline $\begin{array}{l}\text { GenotypesXSubstrates } \\
\text { interaction }\end{array}$ & $11.38^{*}$ & $8.29 \mathrm{~ns}$ & $0.29 \mathrm{~ns}$ & $0.29 \mathrm{~ns}$ \\
\hline
\end{tabular}

Means with the same letter down the group are not significantly different from each other at $5 \%$ level of significance. LSD: Least significant difference, SE: Standard error, DT50\%F: Days to 50\% flowering, DTFruiting: Days to fruiting, NOF: Number of fruits and FW: Fruit weight.

\section{DISCUSSION}

Ufoegbune et al. (2014) had earlier reported differences in watermelon varietal response to different climatic conditions as obtained in this study where the BD genotype showed superior agronomic performance to both CS and TSO genotypes. Although the BD genotype had a better agronomic performance compared to other genotype, it was the CS genotype that produced heavier fruits. This could be that the larger leaf area in the CS genotype provided it a larger photosynthetic surface, thus more photosynthates formed in it were channeled to the fruits (Richards, 2000).

On the substrate type, the soil usage outperformed the cocopeat substrate in the number of fruit formed but the fruits in cocopeat substrates were heavier than the ones from soil, although not significant, the reason the differences in their weight was insignificant despite the 
soil having higher number. The improved performance of the watermelon genotypes in soil could be a result of the inert organic manure or nutrients present in the soil before the application of external manure Adediran and Banjoko (2002). Although this findings contradicts the position of Law-Ogbomo and Ajayi (2009) who had a poor amaranthus performance in soil and recommended the use of organic manure to augment the soil, a position earlier held by Egharevba and Ogbe (2002). While it is intrinsic in the fertilization of cocopeat as it does not contain any inert nutrient. However, the hydroponics system had been reportedly used in the production of other vegetables (Ossai et al., 2020) as it ensures all year round vegetable production (Hoang, 2020).

\section{CONCLUSION}

The findings of this study had shown that in domesticating exotic watermelon varieties, it is importance to consider the environmental stability of the variety, as though the DB variety had better growth performance, it was the CS variety that produced bigger fruits which is the economic yield of the plant in Nigeria. However, to ensure the all year round performance of watermelon, the use of cocopeat substrate is important as the fruit weight obtained in it is same with the soil farming which contained additional inert nutrient to the ones used in fertigating the plants. Thus the CS variety and cocopeat substrate is recommended for vertical farming in Nigeria, while further research can be done on the mixture of cocopeat and soil in watermelon farming to reduce the cost of purchasing the substrate.

\section{REFERENCES}

Adediran, J. A., \& Banjoko, V. A. (2003). Comparative effectiveness of some compost formulation for maize in Nigeria. Nigerian Journal of Soil Science, 13, 42-48.

Egharevba, R. K. A., \& Ogbe, F. M. (2002). The effects of different levels of organic and mineral fertilizers on the yield performance of two Amaranthus (A. cruentus) cultivars. The Plant Scientists, 3, 62-72.

Hoang, M. (2020). Effects of growing substrates and seed density on yield and quality of radish (Raphanus sativus) microgreens. Research on Crops, 21, 579-586.

Kumar, R., Dia, M., \& Wehner, T. C. (2013). Implications of mating behavior in watermelon breeding. Hort Sci, 48(8), 960-964.

Law-Ogbomo, K., \& Ajayi, S. (2009). Growth and Yield Performance of Amaranthus cruentus Influenced by Planting Density and Poultry Manure Application. Notulae Botanicae Horti Agrobotanici Cluj-Napoca, 37(2), 195-199.

Naz, A., Butt, M. S., Pasha, I., \& Nawaz, H. (2013). Antioxidant Indices of Watermelon Juice and Lycopene Extract. Pakistan Journal of Nutrition, 12(3), 255-260.

Ossai, C. O., Ogbole, S., Balogun, M. O., \& Akpeji, S. C. (2020). Production of Radish (Raphanus sativus L.) in Nigeria Using the Hydroponics System. Journal of Environmental and Agricultural Studies, 1(2), 6-9. 
Peter, O. J. (2018). Herdsmen/farmers conflict and its effects on socio-economic development in Nigeria. Journal of peace, security and development, 4(1), 143-158.

Reetu, D., \& Tomar, M. (2018). Watermelon: A Valuable Horticultural Crop with Nutritional Benefits. pp5.

Richards, R. (2000). Selectable traits to increase crop photosynthesis and yield of grain crops. Journal of experimental botany, 51, 447-458.

Ufoegbune, G. C., Fadipe, O. A., Bello, N. J., Eruola, A. O., Makinde, A. A., \& Amori, A. A. (2014). Growth and Development of Watermelon in Response to Seasonal Variation of Rainfall. ADRRI Journal (Multidisciplinary), 10(10).

\section{Copyrights}

Copyright for this article is retained by the author(s), with first publication rights granted to the journal. This is an open-access article distributed under the terms and conditions of the Creative Commons Attribution license (http://creativecommons.org/licenses/by/4.0). 